\title{
级
}

Al-Dzikra: Jurnal Studi Ilmu al-Qur'an dan al-Hadits

P-ISSN: 1978-0893, E-ISSN: 2714-7916

http://ejournal.radenintan.ac.id/index.php/al-dzikra

Volume 14, No. 2, Desember Tahun 2020, Halaman 239 - 270

DOI: $10.24042 /$ al-dzikra.v14i2.6887

\section{Tradisi Bacaan Al-Qur'an Untuk Ibu Hamil (Studi Murottal Al-Qur'an Dalam Media Youtube)}

\author{
M. Mukhlish Rahman \\ UIN Sunan Kalijaga Yogyakarta \\ mukhlishmuhammad@gmail.com
}

\begin{tabular}{l|l|l}
\hline Received: 22-07-2020 & Revised: 29-09-2020 & Accepted: 20-11-2020 \\
\hline
\end{tabular}

\begin{abstract}
This paper talks about the tradition of reading the Koran for pregnant women, which has been a hereditary culture in society. The letters read during the procession vary, but the most frequently chosen ones are the letters of Yūsuf, Maryam, and Yàsin. The tradition of reciting the Koran to pregnant women is later transformed and adapted to the digital world in the online media YouTube. In which in the uploaded content, it contains the reading of the Koran which in the traditions of the local community is often the choice to read. Therefore, this paper focuses on three problem formulations, first, how is the sacredness of the Koran in the digital world? Second, how is the tradition of reading the Koran for pregnant women in the community? And third, can this tradition be replaced by digital media? The research method is descriptive analytical method by describing the social phenomena that occurs. The approach is a historical-critical approach, by analyzing what are the factors that cause the phenomenon of the tradition of reading the Koran pregnant women to emerge, then it is digitally adapted into the You Tube media. The results of the research that the author gets is that with the rapid development of the times, it does not make
\end{abstract}


the tradition of reading the Koran for pregnant women disappear or be abandoned, but instead this tradition can be transformed and adapted into a digital version. Although, the transformation is only limited to the physical form of reading the al-Qur'an, from the point of view of selecting the letter, it appears that it really adapts the local cultural traditions. The transformation of the tradition of reading the Koran for pregnant women into digital form, in this case You Tube media cannot replace traditions or culture such as mitoni, four months, etc. Because it contains elements of mutual cooperation between communities, which cannot be replaced by online media.

\section{Abstrak}

Tulisan ini berbicara tentang tradisi membaca al-Qur'an untuk ibu hamil yang telah menjadi budaya turun temurun di tengah masyarakat. Adapun surat-surat yang dibaca ketika dalam prosesi tersebut bervariasi, tetapi yang paling sering menjadi pilihan adalah surat Yūsuf, Maryam, dan Yāsinn. Tradisi membacakan al-Qur'an untuk ibu hamil kemudian dalam perkembangannya bertransformasi dan diadaptasi ke dunia digital dalam media online YouTube. Dimana dalam kontenkonten yang diunggah, berisi bacaan al-Qur'an yang dalam tradisi masyarakat lokal sering menjadi pilihan untuk dibaca. Maka dari itu Tulisan ini berfokus kepada tiga rumusan masalah, yaitu pertama, bagaimana sakralitas al-Qur'an di dunia digital ? Kedua, bagaimana tradisi pembacaan al-Qur'an untuk ibu hamil di tengah masyarakat?, dan ketiga, apakah tradisi tersebut dapat digantikan dengan media digital? Metode penelitian yang digunakan adalah metode deskriptif analitis dengan mencoba untuk mendeskripsikan fenomena sosial yang terjadi. Pendekatan yang digunakan adalah pendekatan historis-kritis, dengan menganalisa apa saja faktor yang menyebabkan fenomena tradisi bacaan al-Qur'an untuk ibu hamil muncul, kemudian diadaptasi secara digital ke dalam media You Tube. Hasil penelitian yang penulis dapatkan adalah dengan perkembangan zaman yang pesat, tidak membuat tradisi membaca al-Qur'an untuk ibu hamil menghilang atau ditinggalkan, namun sebaliknya tradisi tersebut dapat bertransformasi dan diadaptasi ke dalam versi digital. Walaupun, transformasinya hanya sebatas bentuk fisik dari membaca al-Qur'an, namun dari segi pemilihan surat tampak bahwa benar-benar mengadaptasi tradisi budaya lokal. Tranformasi tradisi membacakan al-Qur'an untuk ibu hamil ke dalam bentuk digital, dalam hal ini media You Tube tidak dapat 
menggantikan tradisi atau budaya seperti mitoni, empat bulanan, dan lain sebagainya Karena di dalamnya mengandung unsur gotong royong antar masyarakat, yang tidak dapat digantikan dengan media online.

Kata Kunci: Al-Qur'an, Digital, Ibu Hamil, Sakralitas, Tradisi.

\section{A. Pendahuluan}

Perkembangan zaman yang semakin pesat, membuat semua orang saat ini dapat dengan mudah membaca atau mendengarkan ayat-ayat suci al-Qur'an kapan pun dan dimanapun. Tidak seperti zaman dahulu, ketika ingin membaca alQur'an harus dengan mushaf cetak atau sebatas mendengarkan bacaan orang lain yang dapat melantunkannya dengan merdu. Semua itu terbatas oleh ruang dan waktu. Tetapi hari ini, hampir semua orang di dunia mempunyai smartphone, yang didalamnya terdapat banyak sekali aplikasi-aplikasi yang dapat mempermudah kita 'mengakses' al-Qur'an, salah satunya adalah YouTube. YouTube adalah salah satu aplikasi yang paling sering diakses oleh para pengguna jaringan internet, dikarenakan penggunaannya mudah, dan menyediakan berbagai macam konten video yang gratis, dan dapat menghibur juga mengedukasi, khususnya yang berkaitan dengan al-Qur'an. Banyak sekali konten video tentang bacaan ayat suci al-Qur'an yang dilatunkan oleh para qori' dari berbagai belahan dunia, yang diunggah dan dapat diakses secara gratis oleh setiap pengguna aplikasi YouTube. Salah satu yang menarik adalah konten bacaan ayat suci al-Qur'an untuk ibu-ibu yang sedang hamil.

Konten bacaan al-Qur'an untuk ibu hamil, adalah salah satu konten yang telah di unggah oleh banyak channel YouTube, dan juga telah dilihat oleh banyak orang, contohnya, seperti kanal Cahaya Arafah yang memiliki 30.600 suscriber. Kanal tersebut mengunggah konten video tentang bacaan al-Qur'an untuk ibu hamil pada tanggal 22 Agustus 2019, dengan 2 jam, 6 menit, dan 41 detik, dan telah ditonton sebanyak 4.137 .630 kali. Video tersebut berisi bacaan 10 surat (al-Fatihah, Yūsuf, as-Sajadah, Ibrāhīm, Maryam, Luqmān, Yāsīn, al-Ikhlās, al-Falāq, dan anNās) dan juga ditambahkan bacaan ayat kursi. Surat-surat tersebut, dilantunkan oleh beberapa qori' yang berbeda, dan setiap 
satu surat dilantunkan, terdapat keterangan manfaat dari surat yang sedang dilant unkan di dalam videonya. Video tersebut sudah disukai oleh 24 ribu orang dan tidak disukai oleh 2.600 orang. Selain kanal Cahaya Arafah, ada juga kanal Sejuk Channel yang telah memiliki 556 Ribu subscriber juga mengunggah konten video tentang bacaan surat al-Qur'an untuk ibu hamil. Berbeda dengan sebelumnya, video yang diunggah oleh Kanal Sejuk Channel ini hanya berisi bacaan surat Maryam dan Yūsuf saja, tetapi sudah ditonton sebanyak 3 juta kali, dan baru di unggah sekitar 7 bulan yang lalu. Ini menunjukkan bahwa atensi pengguna YouTube terhadap konten ini sangat positif.

Fenomena diatas sangat menarik untuk diteliti, dikarenakan ini adalah sebuah hal baru yang muncul di tengah masyarakat, dan mengindikasikan adanya kecenderungan masyarakat untuk 'berinteraksi' dengan al-Qur'an melalui media digital, daripada langsung secara fisik. Walaupun memang, membaca ayat suci al-Qur'an untuk ibu hamil sudah menjadi tradisi turun temurun di tengah masyarakat, seperti yang dilakukan di tanah Banjar, Kalimantan Selatan. Dalam disertasi Ahmad Rafiq, dijelaskan dengan rinci beberapa tradisi pembacaan al-Qur'an untuk ibu hamil, salah satunya adalah jika belum mengetahui jenis kelamin sang bayi, maka ibunya membaca surat Maryam (19) dan bapaknya akan membaca surat Yūsuf (12), setiap ba'da shalat maghrib. Namun, ketika sudah mengetahui jenis kelamin bayinya, maka keduanya spesifik membaca surat Maryam (19) untuk perempuan dan surat Yūsuf (12) untuk perempuan.

Dalam ranah akademik, penelitian dan kajian mengenai tradisi pembacaan al-Qur'an sebagai media terapi untuk ibu hamil sudah banyak dilakukan, dan berdasarkan penelusuran dapat dibagi menjadi dua kategori, yaitupertama, terapi ketika dalam masa kehamilan sampai trimester ketiga. Biasanya dilakukan untuk menurunkan tingkat kecemasan ibu hamil dalam masa

${ }^{1}$ Ahmad Rafiq, "The Reception Of The Qur'an In Indonesia: A Case Study Of The Place Of The Qur'an In A Non Arabic Speaking Community" (America: Temple University, 2014), hlm. 69. 
kehamilan. $^{2}$ Kedua, terapi untuk menghadapi dan ketika proses persalinan. Terapi dilakukan untuk menurunkan kecemasan ibu hamil terhadap persalinan dan untuk melancarkan proses persalinan. $^{3}$ Dalam kedua proses tersebut, biasanya diputarkan murottal al-Qur' an atau dibacakan langsung.

Dari penelusuran tersebut, terlihat bahwa belum ada penelitian yang secara spesifik membahas bagaimana sejarah pembacaan al-Qur'an menggunakan media digital untuk ibu hamil. Maka dari itu tujuan tulisan ini adalah untuk melengkapi kekurangan penelitian yang telah dilakukan sebelumnya, dengan berfokus kepada tiga rumusan masalah, yaitupertama, bagaimana sakralitas al-Qur'an di dunia digital ?. Kedua, bagaimana tradisi

${ }^{2}$ Wiulin Setiowati, “Pengaruh Terapi Murottal Al-Qur'an Surah Maryam Terhadap Tingkat Kecemasan Pada Ibu Hamil Trimester III," Jurnal Kesehatan STIKES Darul Azhar Batulicin 9, no. 1 (2020); Rosliana Rosliana, "Hubungan Membaca Al-Quran Dengan Tingkat Depresi Pada Wanita Hamil Di Klinik Wihdatul Ummah dan di Klinik Wira Husada Makassar Tahun 2015" (Ph.D Thesis, Universitas Islam Negeri Alauddin Makassar, 2015); Anindita Saparina, "Penerapan Terapi Murottal Al-Qur'an Terhadap Kecemasan Ibu Hamil Primigravida Trimester Pertam: Studi Kasus di Desa Balonggandu Kecamatan Jatisari Kabupaten Karawang" (Ph.D Thesis, UIN Sunan Gunung Djati Bandung, 2019); Sartika Zainal, "Kecemasan Ibu Hamil Anak Pertama Pada Trimester Ketiga Ditinjau dari Intensitas Membaca Al-Qur'an" (Ph.D Thesis, University of Muhammadiyah Malang, 2017); Umi and Mubarak, "Korelasi Antara Kebersyukuran Terhadap Kecemasan Menghadapi Persalinan Pada Ibu Hamil Trimester Tiga Di Banjarmasin," Jurnal Psikologi UIN Sultan Syarif Kasim 13, no. 1 (2017), hlm. 73-80.

${ }^{3}$ Indah Trianingsih, "Pengaruh Murotal Al-Qur'an dan Dzikir Terhadap Intensitas Nyeri Kala I Persalinan," Jurnal Ilmiah Keperawatan Sai Betik 15, no. 1 (2019): 26-30; Sari Wahyuni, Nurul Komariah, and Nesi Novita, "Perbedaan Nyeri Persalinan Pada Ibu Yang Mendapatkan Terapi Murottal Qur'an Dan Musik Klasik di Klinik Bersalin Kota Palembang," JPP (Jurnal Kesehatan Poltekkes Palembang) 14, no. 2 (2019): 107-112; Rusfita Retna, "Pengaruh Terapi Murottal Al-Qur'an Terhadap Penurunan Nyeri Pada Ibu Bersalin di Puskesmas Wilayah Kabupaten Banjarnegara" (PhD Thesis, Universitas' Aisyiyah Yogyakarta, 2017); Suprapti and Maulidta Wirawati, "Upaya Penurunan Intensitas Nyeri Persalinan Kala 1 Fase Aktif Dengan Murottal Al-Qur'an Di Rumah Sakit Umum Daerah Kota Semarang," Jurnal Manajemen Asuhan Keperawatan 1, no. 2 (2017): 31-36; Wahida Azis, M. Nooryanto, and Sri Andarini, "Terapi Murotal Al-Qur'an Surat Arrahman Meningkatkan Kadar B-Endorphin Dan Menurunkan Intensitas Nyeri Pada Ibu Bersalin Kala I Fase Aktif," Jurnal Kedokteran Brawijaya 28, no. 3 (2015), hlm. 213-216. 
pembacaan al-Qur' an untuk ibu hamil di tengah masyarakat ?, dan ketiga, apakah tradisi tersebut dapat digantikan dengan media digital ?Metode penelitian yang digunakan adalah metode deskriptif analitis dengan mencoba untuk mendeskripsikan atau menjelaskan fenomena sosial yang terjadi. Pendekatan yang digunakan adalah pendekatan historis-kritis, dengan menganalisa apa saja faktor yang menyebabkan fenomena tradisi bacaan alQur'an untuk ibu hamil muncul, kemudian diadaptasi secara digital ke dalam media You Tube.

Tulisan ini didasarkan pada asumsi bahwa al-Qur'an adalah kitab suci yang dijadikan pedoman kehidupan bagi seluruh umat Islam dan siapapun atau apapun yang dekat dengannya menjadi mulia. Media digital adalah suatu hal yang baru, dan dapat memudahkan kita untuk berinteraksi dengan al-Qur'an, tetapi tidak menutup kemungkinan jika al-Qur'an diletakkan pada media digital, sakralitasnya akan berkurang, karena kemudahan untuk mengaksesnya memungkinkan untuk dibaca atau diperdengarkan dalam ruang-ruang yang kurang pantas.

\section{B. Sakralitas Al-Qur'an di Dunia Digital}

Definisi sakral menurut Nurdinah Muhammad ${ }^{4}$ dalam tulisannya adalah hal-hal yang lebih dapat dirasakan daripada dilukiskan, karena nilai sakralitas dari suatu benda diantara masyarakat berbeda, misalnya seekor lembu. Bagi masyarakat yang beragama Hindu, lembu adalah hewan yang dianggap suci dan sangat dihormati. Dilarang keras bagi umat Hindu untuk menyakiti atau melukainya. Berbeda dengan masyarakat yang tidak beragama Hindu, yang menganggap lembu adalah hewan biasa dan bahkan dapat dikonsumsi. Selain itu juga terdapat tempat-tempat yang dianggap suci dan dihormati seperti Ka'bah, Masjidil Haram, dan Masjidil Aqsa bagi umat muslim, Bukit Zion bagi umat Yahudi, Kota Vatikan bagi umat Kristiani, Gunung Fuji bagi pemeluk agama Shinto, Zinmalo bagi umat Budha di Laos dan lain-lain. ${ }^{5}$

${ }^{4}$ Nurdinah Muhammad, "Memahami Konsep Sakral dan Profan dalam Agama-Agama," Substantia: Jurnal Ilmu-Ilmu Ushuluddin, Vol. 15, no. 2 (October 15, 2013), hlm. 269.

5 Mircea Eliade, "Mitos Gerak Kembali Yang Abadi, Kosmos Dan Sejarah", terj. Cuk Sumana (Yogyakarta: Ikon Teralitera, 2001), hlm. 13. 
Menurut Emile Durkheim dalam bukunya, bahwa suatu realitas yang mempunyai fungsi sebagai simbol keberadaan sesuatu yang sakral dapat disebut sebagai totemisme. Tetapi, lanjutnya, totem bukanlah sesuatu yang dipuja. Objek yang dipuja sesungguhnya adalah suatu hal sakral yang berada dibalik totem tersebut. ${ }^{6}$ Dengan demikian, pengertian sakral yang lebih luas adalah sesuatu yang terlindung dari pelanggaran, pengacauan atau pencemaran, karena dihormati dan dimuliakan. Maka, sakral tidak hanya terbatas pada sesuatu hal yang berbau keagamaan, tapi juga tempat-tempat kebudayaan, atau gagasan pemikiran yang dianggap mulia.

Sakral berkebalikan dengan profan. Profan adalah suatu hal yang umum, tidak dikuduskan, dan bersifat sementara, artinya dia berada di luar hal-hal religius. ${ }^{7}$ Menurut Emile Durkheim, dunia dapat dibagi menjadi dua, yakni yang berisi semua hal yang suci dan yang lainnya berisi semua hal yang profan. ${ }^{8}$ Lebih rinci, Durkheim menjelaskan dalam bukunya sebagai berikut :

"The real charactheristic of religious phenomena is that they always suppose a bipartite division of the whole universe, known and knowable, into two classes which embrace all that exist, but which radically exclude each other. Sacred things are which the interdictions protect and isolate; profane things, those to which these interdictions are applied and which must remain at a distance from the first. Religious beliefs are the representations which express the nature of sacred things and the relations which they sustain, either with each other or with profane things."9

Agama adalah sistem yang muncul dari sesuatu yang disakralkan, maka agama adalah sistem yang konstan, dan dapat menjadi suatu elemen dalam kehidupan manusia. Fungsi agama harus dilihat sebagai sebuah sebab bukan akibat, karena

${ }^{6}$ Émile Durkheim and Joseph Ward Swain, "The Elementary Forms of the Religious Life" (Courier Corporation, 2008), hlm. 104; Lihat juga Koentjaraningrat, Kamus Istilah Antropolog (Progress bekerja sama dengan Pusat Bahasa, Departemen Pendidikan Nasional, 2003), hlm. 239. 1995), hlm. 87.

Mariasusai Dhavamony, "Fenomenologi Agama" (Jakarta: Kanisius,

${ }^{8}$ Durkheim dan Swain, The Elementary Forms of the Religious Life, hlm. 37.

${ }^{9}$ Durkheim dan Swain, hlm. 41. 
kehidupan sakral berada dalam wilayah supranatural yang sangat penting, tempat dimana segala keteraturan dan kesempurnaan, juga tempat berdiamnya roh para leluhur. Sedangkan kehidupan profan berada dalam wilayah kehidupan sehari-hari yang tidak terlalu penting. ${ }^{10}$

Berbicara mengenai agama, maka tidak dapat dilepaskan dari benda-benda atau peralatan material untuk melakukan upacara peribadatan, karena kesakralan agama terletak pada benda-benda tersebut. Seperti dalam agama Islam, terdapat kitab suci al-Qur'an, Ka'bah, tasbih, sajadah, dan lain sebagainya, yang digunakan untuk mendukung prosesi ibadah. Selain itu, ada tanda salib, gereja, kitab Bible, yang disakralkan oleh penganut agama Kristiani, ada pura, kitab suci Weda yang disakralkan oleh penganut agama Hindu, ada Vihara, kitab Tripitaka, patung Sidharta Gautama, yang disucikan dalan agama Budha, dan ada juga Sinagog, kitab Taurat yang sangat disucikan oleh penganut agama Yahudi. ${ }^{11}$

Menurut Durkheim, secara fisik atau material, bendabenda yang disakralkan sama saja dengan benda lain yang tidak disakralkan, karena manusia atau masyarakat yang mempercayainya sajalah yang menjadikan benda itu sakral atau suci, bukan karena adanya sesuatu yang lain atau istimewa dalam benda tersebut. Anggapan atau kepercayaan sebagai sesuatu yang suci ini datang dari subjek yang menganggap benda itu suci, maka suci atau sakral adalah sifat pasif pada benda yang disucikan atau diskralkan bukan sifat aktif. ${ }^{12}$

Sesuatu hal yang disakralkan harus dihormati, dipuja atau bahkan disembah dalam upacara-upacara tertentu, seperti bulan suci Ramadhan bagi umat Islam. Dalam bulan suci tersebut, seluruh umat Islam diperintahkan untuk menahan makan, minum dan berhubungan seks pada siang hari. Ka'bah sebagai bangunan yang suci, dijadikan sebagai arah tempat untuk menghadap

${ }^{10}$ Muhammad, "Memahami Konsep Sakral dan Profan dalam AgamaAgama," hlm. 271.

11 Agus Bustanuddin, “Agama Dalam Kehidupan Manusia, Pengantar Antropologi Agama" (Jakarta: Raja Grafindo Persada, 2006), hlm. 80-81.

12 Durkheim dan Swain, The Elementary Forms of the Religious Life, hlm. 99. 
shalat, dan dikelilingi dengan membaca bacaan tertentu yang dinamakan thawaf. Bahkan, tanah suci di sekitar Makkah, tempat Ka'bah berada diberlakukan larangan membunuh hewan dan menebang pohon-pohonnya ketika sedang beribadah Haji. Itu semua adalah bentuk penghormatan atas hal-hal yang disakralkan.

Al-Qur'an adalah kitab suci umat Islam yang sangat disakralkan dan dihormati, karena semua aspek ajarannya didasarkan dan disandarkan padanya. Membacanya harus dengan posisi yang sopan, dengan pakaian yang rapi, dan dalam keadaan suci. Menghafalkannya termasuk perbuatan yang mulia, bahkan dalam ilmu Fiqih dikatakan bahwa menghafal al-Qur'an hukumnya wajib kifayah bagi umat Islam. Sehingga apabila terdapat sejumlah orang yang dapat menghafal al-Qur'an hingga mencapai jumlah tertentu, maka gugurlah kewajiban tersebut dari yang lainnya. ${ }^{13}$

Lalu bagaimana jika al-Qur'an sebagai suatu hal yang sakral, diletakkan atau berada dalam suatu hal yang profan seperti media digital ${ }^{14}$, karena profan adalah suatu hal yang biasa, rasional nyata, dan tidak perlu diperlakukan secara istimewa.

Sebagai kitab suci yang sakral dan menjadi pedoman umat Islam, al-Qur'an telah mengalami berbagai macam perkembangan, tetapi perkembangan tersebut bukan dari segi isi namun segi fisiknya. Menurut Ziauddin Sardar, yang dikutip oleh Tati Rahmayani, ada tiga fase perkembangan al-Qur' an dari segi fisiknya; Pertama, pada pertengahan abad ke delapan. Pada saat itu,umat Islam pertama kali mengenal kertas yang berasal dari peradaban Cina, sehingga pada saat itu banyak pengetahuan mengenai keislaman yang dituangkan dengan tulisan tangan kedalam media kertas, termasuk al-Qur'an. Kedua, pada sekitar abad ke sepuluh, padasaat umat Islam mulai mengenal adanya percetakan. Dalam perkembangannya, al-Qur'an mulai dicetak

${ }^{13}$ Yusron Masduki, "Implikasi Psikologis Bagi Penghafal Al-Qur'an," Medina-Te: Jurnal Studi Islam, Vol. 14, no. 1 (2018), hlm. 19.

${ }^{14}$ Media digital adalah segala jenis media yang hanya dapat diakses melalui internet yang beisikan teks, foto, video, dan suara. Lihat Asep Syamsul M Romli dan Asep Syamsul, "Jurnalistik online: panduan praktis mengelola media online," Bandung: Nuansa Cendekia, 2012, hlm. 34. 
dan kemudian disebarluaskan untuk memenuhi kebutuhan masyarakat. Ketiga, pada abad ke dua puluh satu, yang lebih dikenal sebagai era digital. Pada saat ini, al-Qur'an mulai dicetak secara digital, baik dalam bentuk $\mathrm{CD}$, maupun dalam bentuk aplikasi komputer dan smartphone. ${ }^{15}$ Secara umum, al-Qur'an yang berbentuk digital, dapat dibagi dalam beberapa macam sebagai berikut:

\section{Al-Qur'an Pen Digital}

Al-Qur'an pen digital pada dasarnya mirip dengan alQur'an pada umumnya, namun ia dilengkapi dengan pen yang dapat mengeluarkan bacaan al-Qur'an. Cara penggunaannya hanya dengan meletakkan ujung pen yang telah dilengkapi oleh sensor pada ayat al-Qur'an yang ingin didengarkan bacaannya, maka secara otomatis pen tersebut mengeluarkan bacaan alQur'an sesuai yang diinginkan. Selain membaca ayat al-Qur'an, pen tersebut dapat merekam suara.

\section{Software Komputer}

Berikut adalah beberapa software al-Qur'an terbaru yang dapat digunakan di komputer ${ }^{16}$ :

a. Ayat KSU ( King Saud University )

Software al-Qur'an untuk komputer ini adalah buatan King Saud University. Software ini dilengkapi dengan 20 bahasa untuk memudahkan penggunaannya, termasuk bahasa Indonesia. Selain itu, software ini menyediakan salinan dari mushaf Madinah, mushaf Warsh, dan juga terdapat salinan mushaf berwarna yang dilengkapi dengan keterangan ilmu Tajwid. Didalamnya juga terdapat fitur untuk mendengarkan bacaan dari 20 qori' dari seluruh penjuru dunia. Software ini tersedia dalam dua pilihan, offline dan juga online. Keduanya dapat diakses kedalam websitenya. ${ }^{17}$

b. MyQuran Indonesia Lite Quran

${ }^{15}$ Tati Rahmayani, "Pergeseran Otoritas Agama Dalam Pembelajaran AlQur'an," Maghza: Jurnal Ilmu Al-Qur'an Dan Tafsir, Vol. 3, no. 2 (December 28, 2018), hlm. 192.

16 "10 Aplikasi Al Quran Terbaik untuk PC dan Laptop," Carisinyal, 1 Mei 2017, https://carisinyal.com/aplikasi-al-quran-untuk-pc/.

${ }^{17}$ T.t., http://quran.ksu.edu.sa/index.php?1=en\#aya=18_54. 
Aplikasi al-Qur'an ini menarik karena asli buatan Indonesia. Dalam aplikasi ini terdapat fitur yang memudahkan penggunanya untuk mendengarkan bacaan al-Qur'an. Sedikit berbeda dengan aplikasi sebelumnya, aplikasi ini hanya tersedia dalam bentuk offline, jadi dapat di install kedalam komputer dan menghemat kuota internet.

c. Zekr

Aplikasi al-Qur'an satu ini tersedia dan dapat digunakan dengan gratis di computer. Aplikasi ini menyediakan berbagai macam terjemahan al-Qur'an dan dilengkapi berbagai bahasa untuk mempermudah mencari lafadz atau ayat al-Qur'an. Didalamnya juga terdapat fitur murottal al-Qur'an dari berbagai qori' ternama.

\section{Aplikasi Smartphone}

Kemajuan zaman membuat al-Qur'an tidah hanya dapat diakses di komputer tetapi juga dapat melalui smartphone. Berikut beberapa aplikasi al-Qur'an yang ada di smartphone:

a. Al-Qur'an Indonesia

Sesuai dengan namanya, aplikasi ini adalah asli buatan orang Indonesia yaitu Andi Unpam. Didalam aplikasi tersebut disajikan berbagai macam fitur seperti dapat membaca alQur'an dengan mode layar landscape atau portrait. Tersedia juga tema terang dan gelap, ada terjemahan bahasa Indonesia dari Kemenag dan juga Tafsir Jalalain, ada juga audio mp3 murottal lengkap 30 juz dengan 8 pilihan qori', dapat mencari ayat-ayat al-Qur'an hanya berdasarkan kata kunci dalam terjemahan, dan masih banya fitur-fitur pelengkap lainnya seperti jadwal sholat, kalender hijriah, dan penunjuk arah kiblat. ${ }^{18}$

b. Ayat Al-Qur' an KSU

Aplikasi ini adalah versi android dari software Ayat yang telah diuraikan sebelumnya. Fitur didalamnya juga hampir sama yaitu dilengkapi dengan 20 bahasa terjemahan al-Qur'an, ada salinan mushaf al-Qur'an utuh, dapat melakukan pencarian

18 “10 Aplikasi Al Quran Terbaik di Smartphone Android," Carisinyal, 1 Mei 2017, https://carisinyal.com/aplikasi-al-quran-di-android/. 
ayat hanya dengan kata kunci, dan juga menyajikan rekaman terjemahan al-Qur'an dalam dua bahasa, bahasa Arab dan Urdu. Aplikasi ini juga berbahasa Indonesia dan Inggris. ${ }^{19}$

\section{c. Qur'an for Android}

Aplikasi ini adalah buatan dari Qur'an.com yang menyediakan banyak fitur penting yang biasa digunakan seperti mode baca yang jelas, petunjuk halaman yang mudah, dan juga dilengkapi terjemahan al-Qur' an dalam 32 bahasa. ${ }^{20}$

Selain dalam bentuk aplikasi, saat ini al-Qur'an juga berada dalam media-media lainnya, yang berbentuk sebuah kajian atau interaksi dakwah, seperti melalui YouTube. Sebagai media komunikasi yang baru, YouTube mengintegrasikan berbagai bentuk jasa dan kenyamanan bagi para penggunanya untuk menyalurkan informasi yang diinginkan, khususnya mengenai alQur'an. ${ }^{21}$ Kajian al-Qur'an yang berada dalam YouTube biasanya dalam bentuk yang fleksibel dan interaktif. Seperti seorang guru membacakan atau melantunkan ayat al-Qur' an dengan merdu, lalu kemudian penonton diminta untuk mengikutinya. Ada pula yang benar-benar seperti mengajarkancara membaca al-Qur'an secara perlahan, dan uniknya mendapatkan sambutan yang positif karena jumlah orang yang melihatnya banyak. Tetapi dari semua konten mengenai al-Qur'an, murottal al-Qur'an adalah konten yang paling banyak diunggah dan dilihat oleh para pengguna YouTube, karena sangat bervariasi:

\section{Bacaan Al-Qur'an Untuk Ibu Hamil}

1. Tradisi di tengah masyarakat

${ }^{19}$ Roy, "10 Aplikasi Al Quran Terjemahan Terbaik Untuk PC dan HP Android," AndroidPonsel (blog), 18 Desember 2019, https://www.androidponsel.com/7210/aplikasi-al-quran-terbaik-untuk-pc-danhp-android/.

${ }^{20}$ Firman Herdiansyah, "10 Aplikasi Al-Qur'an GRATIS Terbaik 2020," DownloadSoftwareGratisan.com (blog), $26 \quad$ Mei 2017, https://www.downloadsoftwaregratisan.com/aplikasi-alquran-gratis-terbaikandroid/.

${ }^{21}$ Norizan Aripin et al., "'Youtube' Dan Generasi Muda Islam: Satu Pendekatan Kelompok Fokus Dalam Kalangan Pelajar Universiti," Jurnal Komunikasi: Malaysian Journal of Communication 32, no. 1 (2016), hlm. 375. 
Indonesia adalah sebuah negara yang terdiri dari berbagai suku, tradisi dan budaya. Salah satu tradisi unik yang banyak mendapat perhatian masyarakat lokal adalah tradisi dalam proses kehamilan, karena dalam proses tersebut pasti muncul harapanharapan agar bayi dalam kandungan mampu menjadi generasi baik sesuai yang diinginkan oleh orang tuanya. Maka dari itu, dilakukanlah beberapa tradisi yang dianggap mampu untuk mewujudkan harapan-harapan tersebut, seperti dalam budaya Jawa, terdapat beberapa tradisi yang dinamakan neloni dan mitoni atau tingkeban.Neloni sendiri berasal dari kata telu yang mempunyai arti 'tiga', sedangkan mitoni berasal dari kata pitu yang mempunyai arti 'tujuh'. Maksudnya adalah bahwa tradisi neloni dan mitoni atau tingkeban adalah sebuah ritual yang dilakukan pada saat bayi dalam kandungan berusia tiga atau tujuh bulan. $^{22}$

Secara historis, tradisi mitoni tidak lepas dari pengaruh cerita yang berasal dari masa kerajaan Jayabaya (w.1157) di Kediri. Pada saat itu ada seorang wanita bernama Niken Satingkeb yang menikah dengan seorang punggawa kerajaan yang bernama Sadiyo. Pasangan suami istri ini dianugerahi sembilan orang anak, tetapi tidak ada yang berumur panjang. Sadiyo dan Satingkep tidak putus asa, tetap berusaha dan berdo'a agar mempunyai keturunan yang tidak bernasib mirip dengan sebelumnya. Tetapi takdir berkata lain, setelah sekian lama tidak ada tanda-tanda bahwa Satingkep mengandung, maka pergilah Sadiyo menghadap kepada raja Jayabaya untuk meminta petuah dan nasihat. Jayabaya setelah mendengar cerita tersebut merasa iba dan kemudian memberikan petunjuk yang harus dilakukan yaitu pada setiap hari Tumbak (Rabu) dan Budha (Sabtu), Satingkep harus mandi pada pukul 5 sore menggunakan air suci yang diambil menggunakan tempurung kelapa yang disebut bathok disertai membaca doa yang berbunyi :

22 Iswah Adriana, "Neloni, Mitoni Atau Tingkeban: (Perpaduan Antara Tradisi Jawa dan Ritualitas Masyarakat Muslim)," Karsa: Journal of Social and Islamic Culture, Vol. 19, no. 2 (February 17, 2012), hlm. 239. 
"Hong Hyang Hanging Amarta, Martini Sarwa Huma, humaningsun ia wasesaningsun, ingsun pudyo sampurno dadyo manungso. ${ }^{\text {,23 }}$

Setelah mandi, Satingkep harus memakai pakaian yang bersih kemudian dijatuhkan dua butir kelapa gading (yang telah digambari Sang Hyang Wisnu dan Dewi Sri atau Arjuna dan Sumbadara, dengan tujuan agar jika kelak anaknya lahir, ia mempunyai paras cantik atau tampan seperti yang dimaksud dalam gambar) melalui jarak antara perut dan pakaian. Selanjutnya, wanita yang sedang hamil tersebut harus melilitkan daun tebu wulung pada perutnya, yang kemudian dipotong dengan Keris. Singkat cerita, setelah Sadiyo dan Satingkep melaksanakan semua nasehat yang disebutkan oleh raja, ternyata segala yang mereka minta dikabulkan. Sejak saat itu, tradisi ini diwariskan secara turun temurun dan menjadi tradisi wajib bagi masyarakat Jawa. $^{24}$

Adapun secara umum, upacara tradisi untuk wanita hamil dalam budaya Jawa ada empat, yaitu; Pertama, selametan kehamilan pada bulan kedua. Upacara selametan bulan kedua diisi dengan menyajikan nasi sayuran (yang berupa nasi tumpeng beserta sayuran lengkap, dan jenis sayuran harus ganjil, misalnya dengan hitungan angka 5, 7, 9, atau 11 jenis sayuran).Jenang putih (jenang atau bubur berwarna putih yang terbuat dari tepung beras dicampur santan kelapa). Jenang merah (jenang atau bubur berwarna merah, yang terbuat dari beras diberi santan kelapa dan dicampuri gula merah). Jenang merah putih (jenang atau bubur merah yang diatasnya ditaruh jenang putih, dalam porsi setengahsetengah). Jenang boro-boro atau disebut jenang katul (jenang atau bubur yang terbuat dari katul atau kulit ari beras yang lembut berwarna coklat, lalu diberi sisiran gula kelapa dan parutan kelapa), bermacam-macam jajan pasar, buah-buahan, seperti wajik, jadah, cenil, lapis, onde-onde, bengkoang, mentimun, pisang, rambutan, dan duku, dan terakhir kembang borehan. ${ }^{25}$

23 Ignatius Gatut Saksono dan Djoko Dwiyanto, Faham keselamatan dalam budaya Jawa (Yogyakarta: Ampera Utama, 2012), hlm. 133.

${ }^{24}$ Saksono dan Dwiyanto, hlm. 134.

${ }^{25}$ Nanik Herawati, Mutiara Adat Jawa (Klaten: Intan Pariwara, 2010), hlm. 43. 
Kedua, selametan kehamilan pada bulan keempat. Pada bulan keempat, wanita yang hamil juga haruskan untuk mengadakan upacara selametan yang disebut dengan ngupati. Walaupun, sajian yang harus disiapkan tidak sebanyak pada bulan kedua, seperti nasi uduk atau nasi punel yang dibuat menjadi warna kuning (ditambahkan kunyit) dan dilengkapi lauk pauk (sambal goreng ati, daging kerbau, ampela, dan jantung). Kue apem yang terbuat dari beras kemudian di beri ragi, gula dan kelapa, dan terakhir ketupat yang dibentuk khusus (lebih ke kupat sinta, kupat luwer dan kupat jago). ${ }^{26}$

Ketiga, selametan kehamilan pada bulan ketujuh atau mitoni. Upacara mitoni berbeda dengan upacara selametan ketika masa kehamilan dua bulan, empat bulan, dan sembilan bulan, karena pelaksanaannya lebih kompleks. Tahapan pertama yaitu siraman, yang disimbolkan sebagai pembersihan segala perbuatan jahat calon bapak dan ibu bayi. Tahapan kedua yaitu memasukkan telur ayam kampung ke dalam kain calon ibu oleh suaminya. Tahap ini diyakini sebagai perwujudan agar proses kelahiran bayi dapat berjalan dengan lancar. Tahapan ketiga memasukkan kelapa gading muda dari perut atas calon ibu hingga ke bawah, yang dimaksudkan untuk menghindari rintangan saat kelahiran bayi. Tahapan keempat, calon ibu berganti pakaian dalam tujuh motif, dan para tamu diminta untuk memilih mana yang cocok. Tahapan kelima yaitu pemutusan lawe (lilitan benang) atau janur oleh suaminya. Tujuannya mirip, untuk melacarkan persalinan. Tahapan keenam, pemecahan gayung atau periuk oleh calon ibu, yang dimaksudkan ketika nanti calon ibu tersebut mengandung kembali tidak mendapatkan kendala yang berat. Tahapan ketujuh, calon ibu diminta untuk meminum jamu sebagai perwujudan agar bayinya dapat keluar dengan lancar. Tahapan terakhir yaitu mencuri telor, yang dimaksudkan agar proses persalinan nanti berlangsung dengan cepat, seperti pencuri ketika beraksi. ${ }^{27}$

Keempat, selametan kehamilan pada bulan kesembilan. Pada beberapa hari sebelum kelahiran sang bayi, diadakan selametan jenang procot atau yang biasa disebut dengan procotan. Upacara ini dilaksanakan dengan tujuan agar bayi yang dilahirkan

\footnotetext{
${ }^{26}$ Herawati, hlm. 44.

${ }^{27}$ Adriana, "Neloni, Mitoni Atau Tingkeban," hlm. 243.
} 
sehat dan tidak ada kekurangan sedikitpun. Jenang procot adalah jenang yang terbuat dari tepung beras yang diberi cairan gula aren dan ditambahkan pisang raja yang kulitnya telah dikupas. Menariknya, selametan ini tidak hanya dilaksanakan sekali pada kehamilan pertama, tetapi juga pada kehamilan yang ganjil, seperti pada anak ketiga, kelima, dan seterusnya. ${ }^{28}$

Selain tradisi dalam bentuk selametan yang merupakan sebuah akulturasi budaya ${ }^{29}$, ada juga tradisi membacakan tujuh surat al-Qur'an untuk ibu hamil dalam upacara mitoni. Tujuh surat al-Qur'an yang dibaca merupakan pilihan dari tokoh agama setempat, sebagai contoh upacara mitoni di lingkungan Kartasura, Sukoharjo membacakan surat Yāsīn, Maryam, Yūsuf al-Kahfi, alRahman, al-Waqiah, dan al-Mulk. ${ }^{30}$ Di desa Troso, kecamatan Karanganom, kabupaten Klaten membacakan enam surat yang sama (selain al-Kahfi), ditambah surat an-Nur. ${ }^{31}$ Di padukuhan Sembego, kecamatan Depok, kabupaten Sleman, membaca tiga surat yang sama (Yūsuf, Maryam, dan Yāsīn), ditambah surat Muhammad, Luqmān, Taha, an-Nūr. ${ }^{32}$ Perbedaan pemilihan tujuh

28 Muhamad Mustaqim, "Pergeseran Tradisi Mitoni: Persinggungan Antara Budaya Dan Agama," Jurnal Penelitian 11, no. 1 (2017), hlm. 127.

${ }^{29}$ Perlu diketahui bahwa sebelum agama Hindu masuk ke tanah Jawa, kemudian disusul agama Hindu, penduduk local sudah memiliki kepercayaan yang disebut agama Kejawen. Kepercayaan ini dipengaruhi oleh kekuatan alam, benda-benda yang dianggap magis, roh leluhur, makhluk halus pengganggu atau lelembut, dan juga makhluk halus yang mempunyai kedudukan tertinggi yaitu danyang. Selain itu juga banyak ritual-ritual sakral yang dilakukan sebagai persembahan sekaligus meminta perlindungan agar dijauhkan dari mara bahaya dan bencana. Dengan adanya kepercayaan yang terus berlangsung, maka terbentuklah suatu kebudayaan yang jug mendorong munculnya hukum adat. Lihat Suwardi Endraswara, Buku Pinter Budaya Jawa: Mutiara Adiluhung Orang Jawa (Yogyakarta: Gelombang Pasang, 2005), hlm. 84.

${ }^{30}$ Muhammad Fuad Zain and Hasanudin Hasanudin, "Aktualisasi 7 Surat Dalam Tradisi Mitoni," Maghza: Jurnal Ilmu Al-Qur'an Dan Tafsir 3, no. 1 (June 28, 2018), hlm. 48.

31 Fauzan Nasir Muhammad, Ari Hikmawati, dan Islah Gusmian, "Pembacaan Tujuh Surat Pilihan Al-Qur'an Dalam Tradisi Mitoni (kajian Living Al-Qur'an Di Dusun Sumberjo, Desa Troso, Kecamatan Karanganom, Kabupaten Klaten)," 2016, hlm. 49.

32 Siti Mas'ulah, "Tradisi Pembacaan Tujuh Surat Pilihan dalam Ritual Mitoni/Tujuh Bulanan," Skripsi Jurusan Ilmu Al-Qur'an dan Tafsir Fakultas Ushuluddin dan Pemikiran Islam UIN Sunan Kalijaga. Yogyakarta, 2014, hlm. $\mathrm{XV}$. 
surat yang dibacakan dalam upacara mitoni, disebabkan karena pemahaman terhadap makna dan keutamaan dari surat-surat tersebut yang berbeda, dan karena pengalaman dari masyarakat lokal (yang memiliki tradisi warisan masing-masing) yang berbeda. ${ }^{33}$ Dari uraian di atas, terlihat bahwa ada tiga surat yang selalu menjadi pilihan dari setiap daerah, yaitu surat Yūsuf, Maryam, dan Yāsīn. Berikut sedikit gambaran mengenai cerita yang ada di dalam ketiga surat tersebut :

a. QS. Yūsuf

Surat Yūsuf adalah surat ke dua belas dalam al-Qur'an, yang berjumlah 111 ayat. Surat ini termasuk dalam golongan surat Makiyyah, yang terdiri dari 7670 huruf dan 1670 kata. $^{34}$ Surat ini dinamakan Yūsuf karena menceritakan perjalanan hidup Nabi Yūsuf dari masa kanak-kanak hingga dewasa dan menjadi Nabi. Nabi Yūsuf adalah Nabi yang terkenal mendapatkan ketampanan yang luar biasa. Cerita tentang ketampanan Nabi Yūsuf dimulai dari ayat 21 :

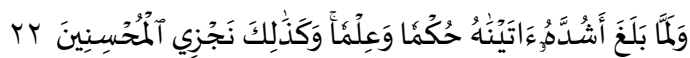

"Dan tatkala dia cukup dewasa Kami berikan kepadanya hikmah dan ilmu. Demikianlah Kami memberi balasan kepada orang-orang yang berbuat baik."

Dalam ayat tersebut dijelaskan bahwa ketampanan Nabi Yūsuf mulai terlihat ketika mencapai usia dewasa, kemudian Nabi Yūsuf dianugerahi Hikmah. ${ }^{35}$ Dalam banyak literatur, usia dewasa Nabi Yūsuf yang dimaksud dalam al-Qur'an diperkirakan sekitar 30-35 tahun. Kemudian cerita berlanjut ketika Nabi Yūsuf menjadi anak tiri dari raja saat itu yaitu Aziz, karena Nabi Yūsuf dimusuhi oleh saudara-saudaranya kemudian dibuang di sumur dan dipungut oleh seorang kemudian dijual. Pada saat ketampanan Nabi Yūsuf mulai

${ }^{33}$ Zain dan Hasanudin, “Aktualisasi 7 Surat Dalam Tradisi Mitoni,” hlm. 48.

${ }^{34}$ Abu Ishaq al -Tsa'labi, Tafsir al-Kasysyaf wa al-Bayan, Vol. 5 (Beirut: Dar Ihya' al-Turas al-'Araby, 2002), hlm. 196.

${ }^{35}$ Hikmah adalah keilmuan aplikatif yang bermanfaat untuk diterapkan, sedangkan ilmu yang dimaksud adalah ilmu yang menakwilkan sesuatu seperti mimpi. Lihat Quraish Shihab, Tafsir Al-Misbah: Pesan, Kesan, dan Keserasian Al-Qur'an, vol. 6 (Jakarta: Lentera Hati, 2002), hlm. 416. 
tampak, terjadilah konflik dengan istri dari sang raja yang diam-diam telah mengamati Nabi Yūsuf sejak mulai masa remaja. Konflik tersebut diceritakan dengan jelas pada ayat 2324:

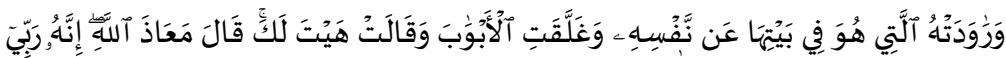

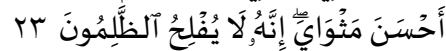

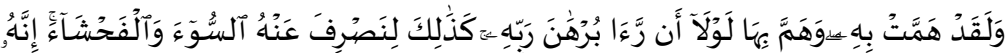

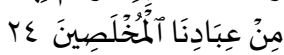

Dan wanita (Zulaikha) yang Yūsuf tinggal di rumahnya menggoda Yūsuf untuk menundukkan dirinya (kepadanya) dan dia menutup pintu-pintu, seraya berkata: "Marilah ke sini". Yūsuf berkata: "Aku berlindung kepada Allah, sungguh tuanku telah memperlakukan aku dengan baik". Sesungguhnya orang-orang yang zalim tiada akan beruntung.

Sesungguhnya wanita itu telah bermaksud (melakukan perbuatan itu) dengan Yūsuf, dan Yūsufpun bermaksud (melakukan pula) dengan wanita itu andaikata dia tidak melihat tanda (dari) Tuhannya. Demikianlah, agar Kami memalingkan dari padanya kemungkaran dan kekejian. Sesungguhnya Yūsuf itu termasuk hamba-hamba Kami yang terpilih.

Pada ayat diatas, diceritakan bahwa suatu hari Nabi Yūsuf yang sudah dewasa dirayu oleh istri raja untuk melakukan hubungan intim. ${ }^{36}$ Rayuan istri raja tidak hanya dalam bentuk verbal, tapi juga tindakan dengan menutup pintu ruangan tempat mereka berdua berada dengan rapat hingga tidak celah untuk Nabi Yūsuf melarikan diri. ${ }^{37}$ Dalam ayat 24 terlihat

${ }^{36}$ Istri raja Aziz dalam riwayat adala seorang wanita yang telah lama tidak berhubungan intim karena suaminya lemah syahwat. Sebagai wanita normal, dia tentu ingin melampiaskan syahwatnya kepada Nabi Yusuf yang rupawan, apalagi istri raja tersebut belum mempunyai keimanan dan ketaqwaan yang kuat shingga dapat dengan mudah dipengaruhi oleh hawa nafsu. Lihat Muhammad Akrom, "Analisis Ketampanan Nabi Yusuf Dalam Perspektif Semiotika Al-Qur'an," Arabiyat: Jurnal Pendidikan Bahasa Arab Dan Kebahasaaraban, Vol. 1, no. 2 (December 31, 2014), hlm. 230.

37 Penggunaan lafadh غلقتyang berasal dari lafadh غلق yang berarti menutup, menunjukkan sebuah aktivitas yang berulang-ulang. Artinya pintu yang ditutup dilakukan secara berulang-ulang untuk memastikan semuanya benar-benar tertutup, dan pintu yang ditutup tidak hanya satu, karena al-Qur'an 
bahwa Nabi Yūsuf adalah seorang manusia yang juga memiliki aspek manusia yaitu kebutuhan biologis, sehingga Nabi Yūsuf hampir tergoda untuk melakukannya, namun di ayat tersebut juga menegaskan aspek kenabiannya yang sadar akan kebesaran Allah SWT, sehingga Nabi Yūsuf mampu mengendalikan hasrat tersebut. Maka dari itu, salah satu faktor surat Yūsuf menjadi pilihan dalam upacara mitoni adalah karena adanya harapan terhadap sang putra nanti ketika menjalani kehidupan dapat menjadi seperti Nabi Yūsuf, yang memiliki ketampanan dan keimanan yang sangat kuat.

b. QS. Maryam

Surat Maryam adalah surat ke 19 dalam al-Qur'an yang berjumlah 98 ayat, dan termasuk dalam golongan surat Makiyyah karena hampir seluruh ayatnya diturunkan sebelum Nabi Muhammad SAW hijrah. Surat ini dinamakan Maryam karena sebagian besar isinya bercerita tentang Maryam dan keluarganya dari Bani Israil. Pada ayat ke 16-21, diceritakan bahwa Maryam adalah seorang wanita yang selalu menjaga kehormatannya, sehingga ia selalu berusaha untuk menjauhkan diri dari laki-laki dan dari kerumunan Bani Israil. Karena pribadinya yang mulia tersebut, Allah SWT mengut us malaikat Jibril untuk menyampaikan kepadanya bahwa ia dipilih menjadi ibu dari Nabi Isa a.s. walaupun dia tidak pernah disentuh oleh laki-laki :

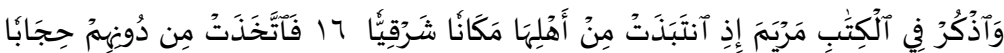

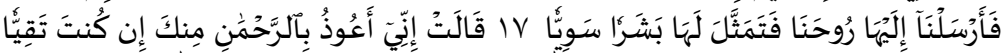

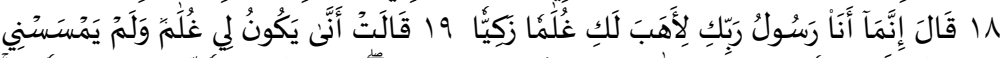

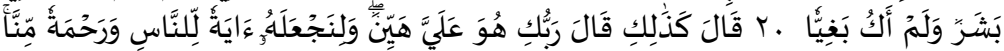

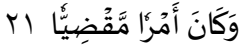

"Dan ceritakanlah (kisah) Maryam di dalam Al Quran, yaitu ketika ia menjauhkan diri dari keluarganya ke suatu tempat di sebelah timur. (17) Maka ia mengadakan tabir (yang melindunginya) dari mereka; lalu Kami mengutus roh Kami kepadanya, maka ia menjelma di hadapannya (dalam bentuk) manusia yang sempurna. (18) Maryam berkata: "Sesungguhnya aku berlindung dari padamu

menggunakan lafadh أبوب. Artinya, tidak ada orang lain dalam ruangan itu selain mereka berdua. Lihat Akrom, hlm. 231. 
kepada Tuhan Yang Maha pemurah, jika kamu seorang yang bertakwa". (19) Ia (jibril) berkata: "Sesungguhnya aku ini hanyalah seorang ut usan Tuhanmu, untuk memberimu seorang anak laki-laki yang suci". (20) Maryam berkata: "Bagaimana akan ada bagiku seorang anak laki-laki, sedang tidak pernah seorang manusiapun menyentuhku dan aku bukan (pula) seorang pezina!" (21) Jibril berkata: "Demikianlah". Tuhanmu berfirman: "Hal itu adalah mudah bagi-Ku; dan agar dapat Kami menjadikannya suatu tanda bagi manusia dan sebagai rahmat dari Kami; dan hal itu adalah suatu perkara yang sudah diputuskan".

Pada ayat 22-30 diceritakan bahwa Maryam mengandung, hingga pada saat akan melahirkan dia pergi ke satu tempat. Kemudian setelah melahirkan, dia kembali dan menunjukkan bayi Noya tersebut kepada kaumnya. Tetapi kaumnya malah menghinanya dan menuduh bahwa Maryam telah berbuat hal yang buruk. Atas Izin Allah SWT, bayi tersebut dapat berbicara dan menunjukkan bahwa Maryam tidak melakukan hal buruk seperti yang mereka tuduhkan :

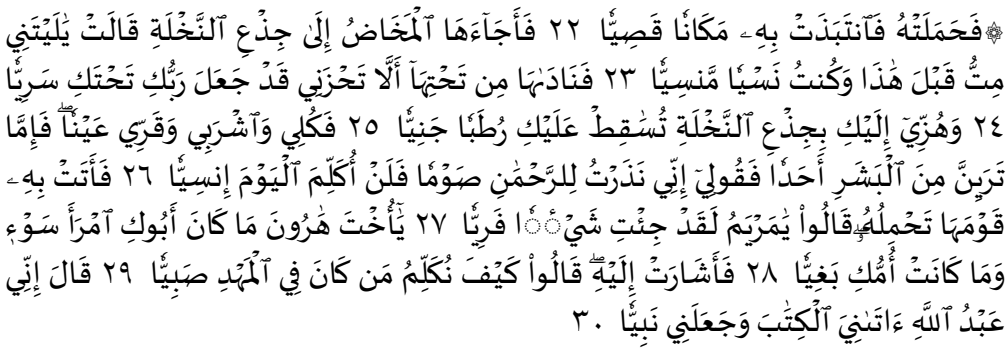

Maka Maryam mengandungnya, lalu ia menyisihkan diri dengan kandungannya itu ke tempat yang jauh. (23) Maka rasa sakit akan melahirkan anak memaksa ia (bersandar) pada pangkal pohon kurma, dia berkata: "Aduhai, alangkah baiknya aku mati sebelum ini, dan aku menjadi barang yang tidak berarti, lagi dilupakan". (24) Maka Jibril menyerunya dari tempat yang rendah: "Janganlah kamu bersedih hati, sesungguhnya Tuhanmu telah menjadikan anak sungai di bawahmu. (25) Dan goyanglah pangkal pohon kurma itu ke arahmu, niscaya pohon itu akan menggugurkan buah kurma yang masak kepadamu. (26) Maka makan, minum dan bersenang hatilah kamu. Jika kamu melihat seorang manusia, maka katakanlah: "Sesungguhnya aku telah bernazar berpuasa untuk Tuhan Yang Maha Pemurah, maka aku tidak akan berbicara dengan 
seorang manusiapun pada hari ini". (27) Maka Maryam membawa anak itu kepada kaumnya dengan menggendongnya. Kaumnya berkata: "Hai Maryam, sesungguhnya kamu telah melakukan sesuatu yang amat mungkar. (28) Hai saudara perempuan Harun, ayahmu sekali-kali bukanlah seorang yang jahat dan ibumu sekalikali bukanlah seorang pezina". (29) Maka Maryam menunjuk kepada anaknya. Mereka berkata: "Bagaimana kami akan berbicara dengan anak kecil yang masih di dalam ayunan?" (30) Berkata Isa: "Sesungguhnya aku ini hamba Allah, Dia memberiku Al Kitab (Injil) dan Dia menjadikan aku seorang nabi.

Cerita Maryam tersebut yang menjadi salah satu alasan dipilihnya surat Maryam menjadi salah satu surat yang dibaca saat upacara mitoni. Dengan membaca surat ini, orang tua sang bayi mengharapkan jika nanti putrinya dapat menjadi seperti Maryam yang dapat selalu menjaga kehormatannya dan mempunyai keimanan yang kuat

c. QS. Yaasin

Surat Yaasin adalah surat ke 36 dalam al-Qur'an. Jumlah ayatnya sebanyak 83, dan termasuk ke dalam golongan surat Makkiyah. Lafadh يس termasuk ke dalam kategori ayat mutasyabihaat, sehingga yang mengetahui maksud dan maknanya hanya Allah SWT. Surat ini berisikan banyak hal, seperti risalah Nabi Muhammad SAW, peringatan tentang ketetapan dan keesaan Allah SWT, serta mengajak kepada manusia untuk berfikir dan merenungi hari akhir. ${ }^{38}$ Membaca surat Yaasin setiap dalam event atau waktu tertentu sudah menjadi bagian dari tradisi masyarakat, karena dianggap memiliki banyak keutamaan, seperti hadis yang diriwayatkan oleh Anas bin Malik :

$$
\begin{aligned}
& \text { عن أنس قال، قال رسول لله صلى لله عليه وسلم : (إن لكل شيء قلبا، وإن قلب القرأن }
\end{aligned}
$$

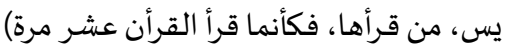

"Dari Anas bin Malik berkata, Rasulullah SAW bersabda : "Sesungguhnya segala sesuatu mempunyai jantung, dan

${ }^{38}$ Wahbah az-Zuhaili, Tafsir al -Wasith, vol. 3 (Damaskus: Dar al-FIkr, 2001), hlm. 2143. 
sesungguhnya jantung al-Qur'an adalah Yāsīn. Barangsiapa yang membacanya, maka seakan-akan membaca al-Qur'an sepuluh kali." 39

Selain riwayat diatas, ada juga riwayat 'Aisyah r.a., tentang barang siapa yang membaca surat Yaasin, akan mendapatkan syafa'at :

$$
\text { و يغفر مستمعة قالت، قال رسول الله صلى لله عليه وسلم : (إن في القرأن لسورة تشفع لقرائها }
$$

"Dari 'Aisyah r.a. berkata, Rasulullah SAW bersabda : “ Sesungguhnya di dalam al-Qur'an terdapat surat yang dapat memberikan syafa'at kepada pembacanya dan mengampuni bagi pendengarnya, yaitu surat Yaasin., 40

Meskipun hadis atau riwayat mengenai keutamaan surat Yaasin bukan hadis yang secara kualitas shahih, bahkan beberapa termasuk hadis yang dhaif atau lemah, budaya membaca surat Yaasin sudah mengakar kuat di tengah masyarakat, apalagi ketika malam jum'at dan upacara kematian. Ini salah satu alasan mengapa surat Yaasin menjadi pilihan ketika dalam upacara mitoni, agar proses kehamilan tersebut mendapatkan keberkahan. Karena seperti dalam salah satu riwayat yang mengatakan bahwa surat Yāsīn dapat mendatangkan manfaat sesuai dengan niat pembacanya.

2. Dalam media YouTube

YouTube sebagai salah satu media digital yang paling sering digunakan saat ini, juga digunakan oleh beberapa orang untuk mempermudah kita mengakses beberapa konten mengenai al-Qur'an, salah satunya adalah konten murottal al-Qur'an untuk ibu hamil. Seperti yang telah dibahas sebelumnnya, bahwa di tengah masyarakat ada tradisi membaca al-Qur'an untuk ibu hamil ketika prosesi upacara tujuh bulanan, yang kemudian diadaptasi dan ditransformasikan kedalam bentuk digital, dalam

${ }^{39}$ Muhammad bin Isa At-Tirmidzi, Jami' Al-Kabir, vol. 5 (Beirut: Dar al-Garb al-Islami, 1998), hlm. 12.

${ }^{40}$ al -Tsa'labi, Tafsir al-Kasysyaf wa al-Bayan, 5:118. 
hal ini YouTube. Berikut beberapa channel YouTube yang mengunggah konten murottal al-Qur' an untuk ibu hamil ${ }^{41}$ :

\begin{tabular}{|c|c|c|c|c|c|c|}
\hline No & $\begin{array}{c}\text { Nama } \\
\text { Channel }\end{array}$ & $\begin{array}{l}\text { Jumlah } \\
\text { Suscriber }\end{array}$ & $\begin{array}{l}\text { Judul } \\
\text { Video }\end{array}$ & $\begin{array}{c}\text { Durasi } \\
\text { Video }\end{array}$ & Isi Video & $\begin{array}{c}\text { Jumlah } \\
\text { Viewer, } \\
\text { Like / } \\
\text { Dislike, } \\
\text { dan } \\
\text { Komentar }\end{array}$ \\
\hline 1 & $\begin{array}{l}\text { Cahaya } \\
\text { Arafah }\end{array}$ & 313.000 & $\begin{array}{l}\text { Murott } \\
\text { al Al- } \\
\text { Qur'an } \\
\text { untuk } \\
\text { Ibu } \\
\text { Hamil } \\
\text { - } \\
\text { Diserta } \\
\text { i } \\
\text { Manfa } \\
\text { at } \\
\text { Setiap } \\
\text { Surat }\end{array}$ & $\begin{array}{l}2 \text { Jam } \\
6 \\
\text { menit } \\
41 \\
\text { detik }\end{array}$ & $\begin{array}{l}\text { Q.S. Al- } \\
\text { Fatihah, } \\
\text { Ayat } \\
\text { Kursi, } \\
\text { Q.S. } \\
\text { Yūsuf, } \\
\text { Q.S. As- } \\
\text { Sajadah, } \\
\text { Q.S. } \\
\text { Ibrāhim, } \\
\text { Q.S. } \\
\text { Maryam, } \\
\text { Q.S. } \\
\text { Luqmān, } \\
\text { Q.S. } \\
\text { Yaasin, } \\
\text { Q.S. Al- } \\
\text { Ikhlas, } \\
\text { Q.S. Al- } \\
\text { Falaq, } \\
\text { Q.S. An- } \\
\text { Nās . }\end{array}$ & $\begin{array}{l}\text { 4,2 Juta, } \\
4.000 / \\
2.600 \text {, } \\
1.500 .\end{array}$ \\
\hline 2 & Sejuk & 560.000 & Surat & 1 jam & Q.S.Mary & 3,1 Juta, \\
\hline
\end{tabular}

41 Data ini dibuat pada tanggal 10 Juni 2020, pukul 19.20. Jika ada perbedaan angka, maka kemungkinan ada penambahan dan pengurangan jumlah yang telah disebutkan dalam tabel. Penulis menggunakan kata kunci "murottal ibu hamil" dalam pencarian aplikai YouTube, untuk mencari konten-konten tersebut. 


\begin{tabular}{|c|c|c|c|c|c|c|}
\hline & Channel & & $\begin{array}{l}\text { Marya } \\
\text { m dan } \\
\text { Surat } \\
\text { Yūsuf } \\
\text { Merdu } \\
\text { Bacaan } \\
\text { Al } \\
\text { Qur'an } \\
\text { Baik } \\
\text { Untuk } \\
\text { Ibu } \\
\text { Hamil }\end{array}$ & $\begin{array}{l}7 \\
\text { menit } \\
28 \\
\text { detik }\end{array}$ & $\begin{array}{l}\text { am, } \\
\text { Q.S. } \\
\text { Yūsuf. }\end{array}$ & $\begin{array}{l}5.000 / \\
2.000, \\
732 .\end{array}$ \\
\hline 3 & $\begin{array}{l}\text { Ika } \\
\text { Rustian } \\
\text { a }\end{array}$ & - & $\begin{array}{l}\text { Bacaan } \\
\text { Surat } \\
\text { Marya } \\
\text { m \& } \\
\text { Surat } \\
\text { Yūsuf } \\
\text { Baik } \\
\text { Buat } \\
\text { Ibu } \\
\text { Hamil }\end{array}$ & $\begin{array}{l}1 \text { jam } \\
12 \\
\text { menit } \\
13 \\
\text { detik }\end{array}$ & $\begin{array}{l}\text { Q.S.Mary } \\
\text { am, } \\
\text { Q.S. } \\
\text { Yūsuf. }\end{array}$ & $\begin{array}{l}5,4 \text { Juta, } \\
2.000 / \\
4.200 \\
1.400\end{array}$ \\
\hline 4 & $\begin{array}{l}\text { Alvinah } \\
\text { Najwa }\end{array}$ & - & $\begin{array}{l}\text { Bacaan } \\
\text { Ayat } \\
\text { Kursi } \\
\& \\
\text { Surat } \\
\text { Yūsuf } \\
\text { Untuk } \\
\text { Ibu } \\
\text { Hamil } \\
\text { Agar } \\
\text { Bayi } \\
\text { Dalam } \\
\text { Kandu } \\
\text { ngn } \\
\text { Selalu } \\
\text { Sehat }\end{array}$ & $\begin{array}{l}16 \\
\text { menit } \\
14 \\
\text { detik }\end{array}$ & $\begin{array}{l}\text { Ayat } \\
\text { Kursi, } \\
\text { Q.S. } \\
\text { Yūsuf. }\end{array}$ & $\begin{array}{l}1,1 \text { Juta, } \\
4.600 / \\
664,530 .\end{array}$ \\
\hline
\end{tabular}




\begin{tabular}{|c|c|c|c|c|c|c|}
\hline 5 & $\begin{array}{l}\text { Taufiqi } \\
\text { Hidaya- } \\
\text { Tullah }\end{array}$ & - & $\begin{array}{l}\text { Surat } \\
\text { Yūsuf } \\
\text { Merdu } \\
\text { Untuk } \\
\text { Ibu } \\
\text { Hamil } \\
\text { Agar } \\
\text { Bayi } \\
\text { Dalam } \\
\text { Kandu } \\
\text { ngn } \\
\text { Sehat } \\
\text { Terlahi } \\
\text { r } \\
\text { Tampa } \\
n\end{array}$ & $\begin{array}{l}29 \\
\text { menit } \\
37 \\
\text { detik }\end{array}$ & $\begin{array}{l}\text { Q.S. } \\
\text { Yūsuf. }\end{array}$ & $\begin{array}{l}\text { 3,3 Juta, } \\
4.000 / \\
2.200 \text {, } \\
1000 \text {. }\end{array}$ \\
\hline
\end{tabular}

Konten-konten yang dimasukkan dalam tabel hanya konten yang memiliki viewer lebih dari 1 juta. Karena banyak channel atau akun YouTube yang mengunggah konten yang mirip tapi hanya mendapatkan viewer atau atensi yang sedikit, seperti channel Suara Islam II, Si Dul Studio, Musqofun, Lusi Susilawati yang memiliki viewer lebih dari 100.000.

Dari semua konten YouTube yang telah dijabarkan diatas, menarik untuk menganalisa salah satu konten yang memiki penonton paling banyak yaitu dari kanal Cahaya Arafah. Video yang diunggah kanal tersebut telah ditonton lebih dari 4 juta orang, dan mendapatkan atensi paling banyak dengan 1500 orang yang memberikan komentar. Konten yang diunggah oleh kanal tersebut juga termasuk yang berisi bacaan surat yang paling banyak, yaitu total 11 surat, sedangkan konten yang lain maksimal hanya sampai 7 surat saja. Mungkin itulah salah satu faktor kenapa konten tersebut memiliki banyak penonton. Walaupun kanalchannel Cahaya Arafah bukan termasuk kanal yang memilik banyak subscriber. Berikut adalah tampilan kanal Cahaya Arafah dan kontennya : 

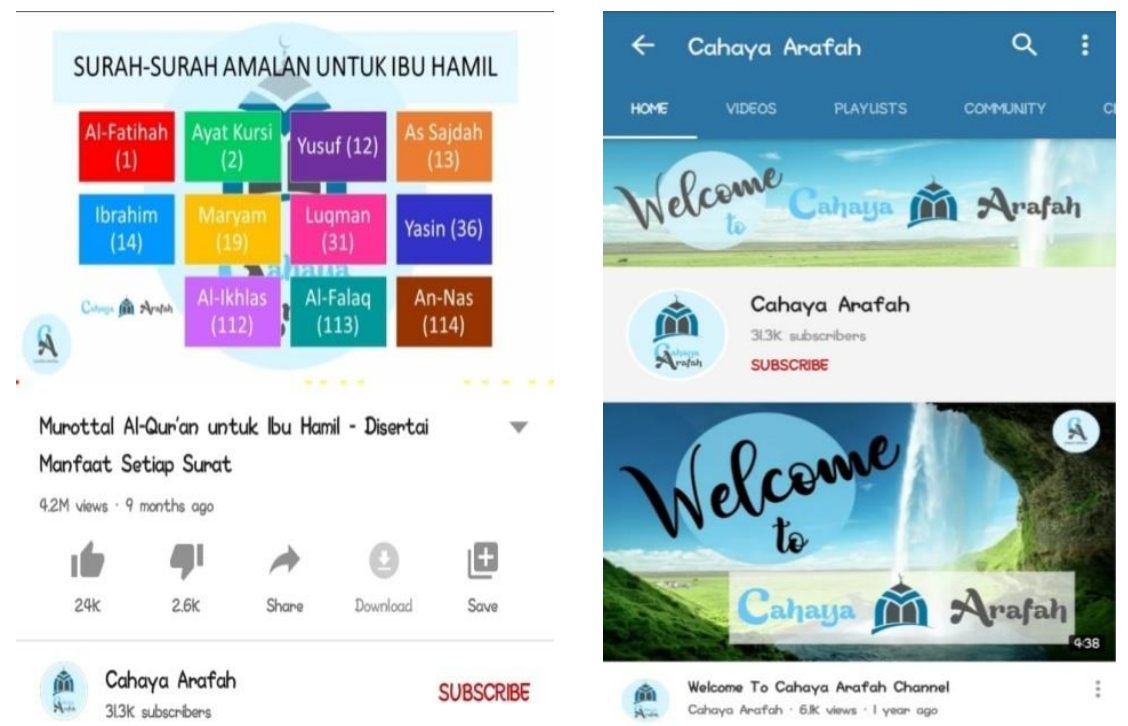

Selain memiliki penonton yang banyak, konten tersebut juga mendapatkan atensi atau komentar sebanyak 1500 an, yang hampir semuanya bernada positif. ${ }^{42}$ Dari komentar-komentar tersebut, terdapat beberapa komentar yang mengatakan bahwa mendapatkan manfaat ketika mendengarkan murottal al-Qur'an, seperti hati menjadi lebih tenang, sang bayi tiba-tiba bergerak. Berikut adalah cuplikan beberapa komentarnya:

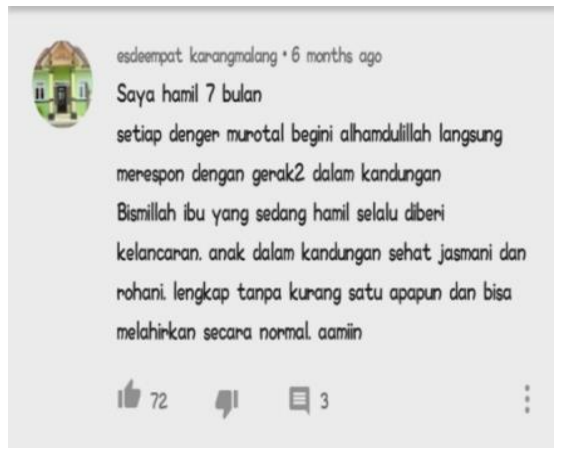

Sonia Wulandari 5 months ago
MasyaAllah. anak dalam kandungan ku nendang terus
sewaktu ak mendengankan ayat alqunan. Sunggh
indah ciptaan mu yaAllah. \&. Semoga anak yg ku
kandung sehat. di beri kesempumaan layaknya
manusia nonmal tanpa ada kekunangan satu pun. Dn
semoga aku bisa lahinan nommal dan selamat. Aamin
yaAllah
It 16

${ }^{42}$ Walaupun hampir sebagian besar akun yang berkomentar dalam video tersebut, tidak dapat diverifikasi apakah akunnya asli dan benar-benar berkomentar dengan kejadian nyata atau tidak, karena setelah ditelursuri ada beberapa yang tidak menampakkan foto profil akun. 
lagi $g$ enak badan. Alhamdulillah skmng tak ajakin dengar murotal ini mendingan jdi tenang sunggh golam Allah tenapi pling mujarab. (4) 310

Semoga nanti si baby bisa lahinan nonmal jdi anak sholeh sholehah Manfaat dunia akhinat. Aamin. Sblo lagi hpl at. at 24 Oktober 2019 \& 118

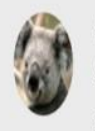

Anggi Ayu Miranti 8 months ago

Aku lagi ngandung anak ku usia nya 19 minggu lg aktif2nya banget genak2. Semoga dengan cana ini anakku bisa jd hafidz/hafidzah al-quanan. Bisa mendoakan kedua onang tuanya nanti. Dilancarkan persalinan dan di sehatkan aku dan anak ku Aamin allahumma aamin bahaba

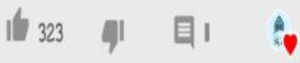

Dari hasil penelusuran banyak juga komentar-komentar yang meminta do'a kepada para penontonnya dan juga mungkin kepada admin channel tersebut, agar proses kehamilan dan juga persalinan yang sedang atau akan dijalani berjalan dengan lancar.Yang menarik, ada juga yang berkomentar agarsegera mendapatkan kesempatan mendapatkan buah hati oleh Allah SWT. Ini menunjukkan bahwa secara tidak langsung ada dampak positif dari video murottal tersebut kepada para pendengarnya.

\section{Kesimpulan}

Dari pembahasan diatas dapat disimpulkan bahwa kesakralan al-Qur'an secara fisik berkurang ketika berada dalam dunia digital, karena dunia digital membuat semua orang dapat dengan mudah mengaksesnya dengan niat apapun, baik ataupun buruk. Tetapi, al-Qur'an secara hakikat adalah sebuah kitab yang suci dimanapun dia berada, maka dari itu bagaimanapun bentuknya, kesakralan al-Qur'an tidak akan berkurang. Sedangkan tradisi membacakan al-Qur'an kepada ibu hamil merupakan sebuah tradisi yang telah lama berada di tengah masyarakat, dan sudah turun temurun dilakukan. Dengan perkembangan zaman yang pesat, tidak membuat tradisi tersebut menghilang atau ditinggalkan, namun sebaliknya tradisi tersebut bertransformasi dan diadaptasi ke dalam versi digital. Walaupun, transformasinya hanya sebatas bentuk fisik dari membaca al-Qur'an, namun dari segi pemilihan surat tampak bahwa benar-benar mengadaptasi tradisi budaya lokal. Transformasi tradisi membacakan al-Qur'an untuk ibu hamil ke dalam bentuk digital, dalam hal ini media You Tube, tidak dapat menggantikan tradisi atau budaya seperti 
mitoni, empat bulanan, dan lain sebagainya. Karena di dalamnya mengandung unsur gotong royong antar masyarakat dalam menyelenggarakan acara tersebut, yang tidak dapat digantikan dengan media online.

\section{Daftar Pustaka}

Adriana, Iswah. "Neloni, Mitoni Atau Tingkeban: (Perpaduan Antara Tradisi Jawa Dan Ritualitas Masyarakat Muslim)." KARSA: Journal of Social and Islamic Culture 19, no. 2 $(17$ Februari 2012): 238-47. https://doi.org/10.19105/karsa.v19i2.69.

Akrom, Muhammad. "Analisis Ketampanan Nabi Yusuf Dalam Perspektif Semiotika Al-Qur'an." Arabiyat: Jurnal Pendidikan Bahasa Arab Dan Kebahasaaraban 1, no. 2 (31 Desember 2014):

223-36. https://doi.org/10.15408/a.v1i2.1141.

Al-Tsa'labi, Abu Ishaq. Tafsir Al-Kasysyaf Wa al-Bayan. Vol. 5. Beirut: Dar Ihya' al -Turas al -'Araby, 2002.

Aripin, Norizan, Awan Ismail, Mohd Sobhi Ishak, Nik Adzrieman Abdul Rahman, Mohd Nizho Abdul Rahman, Mot Madon, dan Mohd Faisal Mustaffa. "'Youtube' Dan Generasi Muda Islam: Satu Pendekatan Kelompok Fokus Dalam Kalangan Pelajar Universiti." Jurnal Komunikasi: Malaysian Journal of Communication 32, no. 1 (2016). http://ejournals.ukm.my/mjc/article/view/14782.

At-Tirmidzi, Muhammad bin Isa. Jami' Al-Kabir. Vol. 5. Beirut: Dar al-Garb al-Islami, 1998.

Azis, Wahida, M. Nooryanto, dan Sri Andarini. “Terapi Murotal Al-Qur'an Surat Arrahman Meningkatkan Kadar BEndorphin Dan Menurunkan Intensitas Nyeri Pada Ibu Bersalin Kala I Fase Aktif." Jurnal Kedokteran Brawijaya 28, no. 3 (2015). 
Bustanuddin, Agus. "Agama Dalam Kehidupan Manusia, Pengantar Antropologi Agama". Jakarta: Raja Grafindo Persada, 2006.

Carisinyal. "10 Aplikasi Al Quran Terbaik di Smartphone Android," 1 Mei 2017. https://carisinyal.com/aplikasi-alquran-di-android/.

Carisinyal. "10 Aplikasi Al Quran Terbaik untuk PC dan Laptop," 1 Mei 2017. https://carisinyal.com/aplikasi-al-quranuntuk-pc/.

Dhavamony, Mariasusai. Fenomenologi Agama. Jakarta: Kanisius, 1995.

Durkheim, Émile, dan Joseph Ward Swain. The Elementary Forms of the Religious Life. Courier Corporation, 2008.

Eliade, Mircea. Mitos Gerak Kembali yang Abadi, Kosmos dan Sejarah. Yogyakarta: Ikon Teralitera, 2001.

Endraswara, Suwardi. Buku Pinter Budaya Jawa: Mutiara Adiluhung Orang Jawa. Yogyakarta: Gelombang Pasang, 2005.

Herawati, Nanik. Mutiara Adat Jawa. Klaten: Intan Pariwara, 2010.

Herdiansyah, Firman. "10 Aplikasi Al-Qur'an Gratis Terbaik 2020." DownloadSoftwareGratisan.com (blog), 26 Mei 2017.

https://www.downloadsoftwaregratisan.com/aplikasialquran-gratis-terbaik-android/.

Koentjaraningrat. Kamus istilah antropolog. Progress bekerja sama dengan Pusat Bahasa, Departemen Pendidikan Nasional, 2003.

Masduki, Yusron. "Implikasi Psikologis Bagi Penghafal AlQur'an." Medina-Te : Jurnal Studi Islam 14, no. 1 (2018): 18-35. https://doi.org/10.19109/medinate.v14i1.2362.

Mas'ulah, Siti. "Tradisi Pembacaan Tujuh Surat Pilihan dalam Ritual Mitoni/Tujuh Bulanan." Skripsi Jurusan Ilmu AlQur'an dan Tafsir Fakultas Ushuluddin dan Pemikiran Islam UIN Sunan Kalijaga. Yogyakarta, 2014. 
Muhammad, Fauzan Nasir, Ari Hikmawati, dan Islah Gusmian. "Pembacaan Tujuh Surat Pilihan Al-Qur'an Dalam Tradisi Mitoni (kajian Living Al-Qur'an Di Dusun Sumberjo, Desa Troso, Kecamatan Karanganom, Kabupaten Klaten)," 2016.

Muhammad, Nurdinah. "Memahami Konsep Sakral dan Profan dalam Agama-Agama." Substantia: Jurnal Ilmu-Ilmu Ushuluddin 15, no. 2 (15 Oktober 2013): 266-78. https://doi.org/10.22373/subtantia.v15i2.4900.

Mustaqim, Muhamad. "Pergeseran Tradisi Mitoni: Persinggungan Antara Budaya Dan Agama." Jurnal Penelitian 11, no. 1 (2017).

Rafiq, Ahmad. "The Reception Of The Qur'an In Indonesia: A Case Study Of The Place Of The Qur'an In A Non Arabic Speaking Community". America: Temple University, 2014.

Rahmayani, Tati. "Pergeseran Otoritas Agama Dalam Pembelajaran Al-Qur'an." Maghza: Jurnal Ilmu Al-Qur'an Dan Tafsir 3, no. 2 (28 Desember 2018): 189-201. https://doi.org/10.24090/maghza.v3i2.2133.

Retna, Rusfita. 'Pengaruh Terapi Murottal Al-Qur'an Terhadap Penurunan Nyeri Pada Ibu Bersalin Di Puskesmas Wilayah Kabupaten Banjarnegara." PhD Thesis, Universitas' Aisyiyah Yogyakarta, 2017.

Romli, Asep Syamsul M, dan Asep Syamsul. "Jurnalistik online: panduan praktis mengelola media online." Bandung: Nuansa Cendekia, 2012.

Rosliana, Rosliana. "Hubungan Membaca Al-Quran Dengan Tingkat Depresi Pada Wanita Hamil Di Klinik Wihdatul Ummah Dan Di Klinik Wira Husada Makassar Tahun 2015." PhD Thesis, Universitas Islam Negeri Alauddin Makassar, 2015.

Roy. "10 Aplikasi Al Quran Terjemahan Terbaik Untuk PC dan HP Android." AndroidPonsel (blog), 18 Desember 2019. https://www.androidponsel.com/7210/aplikasi-al-quranterbaik-untuk-pc-dan-hp-android/. 
Saksono, Ignatius Gatut, dan Djoko Dwiyanto. Faham keselamatan dalam budaya Jawa. Yogyakarta: Ampera Utama, 2012.

Saparina, Anindita. "Penerapan Terapi Murottal Al Quran Terhadap Kecemasan Ibu Hamil Primigravida Trimester Pertam: Studi Kasus Di Desa Balonggandu Kecamatan Jatisari Kabupaten Karawang." PhD Thesis, UIN Sunan Gunung Djati Bandung, 2019.

Setiowati, Wiulin. "Pengaruh Terapi Murottal Al-Qur'an Surah Maryam Terhadap Tingkat Kecemasan Pada Ibu Hamil Trimester Iii." Jurnal Kesehatan STIKES Darul Azhar Batulicin 9, no. 1 (2020).

Shihab, Quraish. Tafsir Al-Misbah : Pesan, Kesan, dan Keserasian Al-Qur'an. Vol. 6. Jakarta: Lentera Hati, 2002.

Suprapti, Suprapti, dan Maulidta Karunianingtyas Wirawati. "Upaya Penurunan Intensitas Nyeri Persalinan Kala 1 Fase Aktif Dengan Murottal Al-Qur'an Di Rumah Sakit Umum Daerah Kota Semarang." Jurnal Manajemen Asuhan Keperawatan 1, no. 2 (2017).

Trianingsih, Indah. "Pengaruh Murotal Al Qur'an dan Dzikir terhadap Intensitas Nyeri Kala I Persalinan.” Jurnal Ilmiah Keperawatan Sai Betik 15, no. 1 (2019).

-Tsa'labi, Abu Ishaq al. Tafsir al-Kasysyaf wa al-Bayan. Vol. 5. Beirut: Dar Ihya' al -Turas al -'Araby, 2002.

Umi, Umi, dan Mubarak Mubarak. "Korelasi Antara Kebersyukuran Terhadap Kecemasan Menghadapi Persalinan Pada Ibu Hamil Trimester Tiga Di Banjarmasin.” Jurnal Psikologi UIN Sultan Syarif Kasim 13, no. 1 (2017).

Wahyuni, Sari, Nurul Komariah, dan Nesi Novita. "Perbedaan Nyeri Persalinan Pada Ibu Yang Mendapatkan Terapi Murottal Qur'an Dan Musik Klasik Di Klinik Bersalin Kota Palembang." JPP (Jurnal Kesehatan Poltekkes Palembang) 14, no. 2 (2019).

Zain, Muhammad Fuad, dan Hasanudin Hasanudin. "Aktualisasi 7 Surat Dalam Tradisi Mitoni." MAGHZA: Jurnal Ilmu Al- 
Qur'an Dan Tafsir 3, no. 1 (28 Juni 2018): 45-60. https://doi.org/10.24090/maghza.v3i1.1953.

Zainal, Sartika. "Kecemasan Ibu Hamil Anak Pertama Pada Trimester Ketiga Ditinjau Dari Intensitas Membaca AlQuran." PhD Thesis, University of Muhammadiyah Malang, 2017.

Zuhaili, Wahbah az-. Tafsir al -Wasith. Vol. 3. Damaskus: Dar alFIkr, 2001.

T.t. http://quran.ksu.edu.sa/index.php?l=enaya $=18 \_54$. 